\title{
The MTST Politics of Social Rights: Counter-Conducts, Acts of Citizenship and a Radical Struggle Beyond Housing
}

\author{
Alberto Fierro ${ }^{1}$ \\ Published online: 17 April 2020 \\ (C) The Author(s) 2020
}

\begin{abstract}
The Brazilian Movimento dos Trabalhadores sem Teto (MTST)-Homeless Workers' Movement-is a social movement that struggles for housing and for a radical transformation of capitalistic socio-economic relations. The present paper offers a problematization of the movement's plea to social rights. They are part of the movement's discourse and strategy. However, the activists' objective is more radical: they aim at a complete transformation of the Brazilian economy and society. By first discussing two sets of literatures-Critical Legal Theory and Governmentality Studies - this article illustrates the complexity and the ambivalences of a radical politics of rights. Then, by contrasting my ongoing ethnographic research with the work of James Holston and Lucy Earle, I discuss the relevance of a citizenship framework for the MTST's struggle. Finally, inspired by Foucault's concept of counter-conducts, the article argues that the movement's politics of rights represents an effective tactic to contrast neoliberal governmentality and to create radical democratic spaces of struggle and collective resistance.
\end{abstract}

Keywords Social movements $\cdot$ Rights $\cdot$ Brazil $\cdot$ Counter-conducts $\cdot$ Urban struggles

Section 1 and parts of section 2.2 were published in Spanish in Relaciones Internacionales 39 (2018), Sobre la Resistencia: discusiones desde las Relaciones Internacionales, in an article titled '¿Cooptación o resistencia? Problematizando las estrategias legales y derechos de los movimientos sociales en el dominio socio-económico’ [Co-optation or resistance? Problematizing legal strategies and rights for social movements in the socio-economic domain], 81-101.

Alberto Fierro

Fierro_Alberto@phd.ceu.edu

1 Doctoral School of Political Science, Public Policy and International Relations, Central European University, Budapest 1051, Hungary 


\section{Introduction: the MTST and Fieldwork at the Marielle Vive Occupation}

The Movimento dos Trabalhadores sem Teto (MTST)-Homeless Workers' Movement-is a Brazilian social movement which recently celebrated 20 years of existence. It operates at the national level, although its stronghold is in the state of São Paulo and the other major cities of the country. The MTST developed out of the concrete housing needs of people moving from the countryside to the urban peripheries, and it was first established under the guidance of MST (Landless Workers' Movement-Movimento dos Trabalhadores sem Terra) activists, yet it became very soon independent. The MTST is a radical leftist movement, this is clearly understandable through the reference to the term worker.

MTST's most important activity is to organise occupations of unused land in the urban peripheries. There, activists build thousands of shacks made of black canvas. Occupations address the problem of housing and serve the goal of organising people to advance the political struggle. This is sketched out on their website:

MTST's most important objective is the struggle against capital and the state which represents capitalist interests. [...] This is why our struggle is much broader than the conquest of a piece of land. But it takes an intense and long accumulation of forces to reach our main goals. All our actions must be directed towards strengthening our path towards these goals (MTST, n.d.).

Over time, the MTST has changed its strategy and increased the number of activists (see Goulart 2011). In 2013, the movement established the occupation Copa do Povo (People's Cup), which marked the beginning of a rapid expansion in the city of São Paulo. When I encountered the movement in April 2018, activists were preparing for the presidential campaign of Guilherme Boulos (one of the MTST key leaders), who ran as presidential candidate for a small leftist party (PSOL_Partido Socialismo e Libertade-Socialism and Liberty Party) in the elections of October 2018. Despite the energies invested in the campaign, the movement was able to launch two new occupations by the end of April. I conducted most of my fieldwork with the MTST at the Marielle Vive occupation-Marielle Lives (named after Marielle Franco, a PSOL city councillor of Rio de Janeiro who was brutally assassinated in March 2018) - in the northern periphery of São Paulo. I employed ethnographic methods, spending many days and nights at the occupation, although I never continuously lived there. I participated in various activities at Marielle Vive, from assemblies and demonstrations to helping in the central kitchen and cleaning common spaces. Fridays, I usually joined occupiers for the movie night, and most of the time, I just spent time hanging out with people, smoking cigarettes and chatting.

At Marielle Vive, MTST activists organised about three thousand families from the northern periphery. People came spontaneously after the first few days. Each new activist had to build her or his shack - which represented the future house - and had to participate in Marielle Vive's activities. The most important objective of MTST occupations is to mobilise people to get suitable housing for the occupiers. They stage protests outside of municipal and state institutions to push for political negotiations. Often, the movement manages to get housing through a public programme called Minha Casa, Minha VidaMy Home, My Life: through this programme, the government buys a suitable piece of land and the Brazilian public bank guarantees low-interest rate loans to occupiers. The movement maintains control over the housing project throughout the entire period of construction work. 
The people who join MTST occupations often are not politicised: their encounter with the movement radically transforms them. Marielle Vive's activists organised meetings to discuss various political issues: from the right to housing, to the capitalistic economic system. Other MTST activists came to the occupation to provide legal and medical help to newcomers, and some organised the collective reading of a book authored by Boulos (2014), which acquaints them with the MTST history and struggle. Occupations are disruptive acts which transform activists' subjectivities. The scholar Engin Isin (2009), in his effort to develop a conceptualisation of citizenship that overcomes the strict duality of an institution labelled either as controlling or as empowering, proposes the dynamic notion of acts of citizenship. In avoiding legalistic characterisations, Isin advances a definition that focuses on politics (and politicisation):

We can define acts of citizenship as those acts that transform forms (orientations, strategies, technologies) and modes (citizens, strangers, outsiders, aliens) of being political by bringing into being new actors as activist citizen (that is, claimants of rights) through creating or transforming sites and stretching scales. (2009, p. 393).

Isin imagines acts as creative enterprises and as interruptions in the routine of a given body politic; they are 'ruptures that enable actors (that the act creates) to create a scene rather than follow a script' (2009, p. 397). Bridging his understanding of acts with a fluid understanding of citizenship, he imagines acts of citizenship as politicising deeds which produce new subjects of rights. Indeed, it is possible to conceptualise MTST occupations in line with Isin's notion: at Marielle Vive, people collectively became political through the learning process of their right to housing. Activists there started something unexpected: they created a political scene which enabled negotiating new relationships with governmental institutions.

It is remarkable that during my field research with the MTST not once did I hear a reference to the concept of citizenship or citizen. The MTST does not conceptualise its struggle for housing through a citizenship framework. Activists do not even employ the term for rhetorical purposes. In the second section of this paper, I will discuss this issue in the light of the work of James Holston (2008) and Lucy Earle (2012), both of whom have extensively researched Sao Paulo's urban movements and respectively coined the terms insurgent and transgressive citizenship.

However, the purpose of the present paper is not to extensively engage with scholarship on citizenship; I believe that critical approaches - as the one Isin brings forward-represent fruitful frameworks to understand the complex relations between people's struggle and government responses. It is not necessary to witness social movements' direct reference to the term citizenship to fruitfully apply Isin's notion of acts of citizenship. Yet, my aim is not to frame the MTST politics of rights in the light of Isin's concept; this paper addresses the centrality of the political struggle - in Portuguese, a luta - for MTST rights politics.

The movement employs rights discourse to politicise occupiers and to develop strategies that transform power relations between the governed and the governors. Following the Foucauldian idea of counter-conducts, ${ }^{1}$ I will argue that the MTST strategically employs legality and rights discourse to redirect and reshape force relations. Yet, this politics of rights is not void of inherent tensions, as the movement develops at the same time a more radical politics. Before moving to the analysis of the MTST politics of rights in the second section, I

\footnotetext{
${ }^{1}$ Counter-conducts are tactics that the governed use to escape and subvert government. However, counterconducts are not external to contemporary governmental techniques (Foucault 2007).
} 
first problematise a politics of rights by surveying two different sets of academic literatures. Even though these discussions mostly refer to the juridical culture of the USA, they provide insightful inspiration to reflect on Brazil, a country which codified social rights in the Constitution of 1988 .

\section{What Is a Politics of Rights?}

\section{The Critical Legal Theory Perspective}

Critical Legal scholarship has been sceptically looking at rights and the law, foreseeing deradicalisation and co-optation of protests. Academics like Brown (1995, 2000, 2004); (Brown and Halley 2002) have long warned that rights are inescapably inscribed into the liberal political order, and therefore, they cannot induce any substantial change in the capitalistic socio-economic relationships. Social movements which decide to use legal strategies and rights discourse in their struggles may have to suffer the dangerous effects of the law: the benefits of an instrumental use of these tools have to be counter-balanced with the risks of cooptation by dominating powers and the de-radicalisation induced by the technicalities of the law.

The role of rights and of courts - and more generally, the law - in developing progressive politics has been debated by socio-legal scholars for almost four decades (see, e.g. McCann 2006; Rosenberg 1991). In 1978, Stuart Scheingold (2004) coined the term 'the myth of rights' to underline how rights are social constructs. He shows how legal rights are not directly empowering but rather their effectiveness depends on external socio-political conditions. He thus discusses the politics of rights to demonstrate how the latter can be used as political resources by the oppressed, by activists and by lawyers. Scheingold's idea that rights are not inherently empowering or disempowering, but that there exists a set of conditions under which progressive politics can develop, stimulated a research agenda conducted by socio-legal scholars and political scientists (see, e.g. Epp 1998; McCann 1994; Sarat and Scheingold 2006). Yet, this debate has mostly overlooked the fact that the very idea of rights is part and parcel of the liberal political order.

In contrast, the tradition of Critical Legal Studies (CLS) engaged with the risks intrinsically associated with progressive legalism. In the USA, CLS academics formulated radical critiques of the usefulness of rights for progressive political projects from the mid-1980s (see Gabel 1984; Tushnet 1984). Duncan Kennedy, a well-known scholar of this tradition, has contributed to the debate on the role of law by specifying how, in the USA, rights discourse has usually focused on 'equality of protection' rather than 'equality of income distribution' (2002, p. 182), thereby not being able to call into question the fundamental socio-economic structures which create oppression. Similarly to CLS, Brown has argued that rights are inescapably inscribed in liberalism. Therefore, they may be successful in obtaining certain objectives in the short run, but they also may fail to be progressive tools for radical social change in the long run. Rights bring forward an individualistic conception of society, and social movements that decide to employ rights strategies in their struggle may end up weakened and co-opted by the very powers they oppose.

Brown points to several problems in the very idea of rights. First, they relate mainly to individuals rather than social groups, and therefore coexist with an individualistic conception of society. Second, the 'implicit promise of the liberal state is that it will attempt to make 
justice happen by means of law' (Brown and Halley 2002, p. 12); therefore, rights are not effective tools for achieving social progress outside of that political order. Thus, rights represent 'a mitigation - but not a resolution — of subordinating powers' (Brown 2000, p. 231). Moreover, she claims that rights have an individualising effect on collective political communities: 'at the moment a particular "we" succeeds in obtaining rights, it loses its we-ness and dissolves into individuals' (Brown 1995, p. 87). Because rights are most typically attributed to individuals, their strategic use may harm the collective political effort by transforming it into a recognition of individual entitlements. According to Brown, this effect is somehow intrinsic to their functioning logic. In addition to this problem, collectivities which start from an advantaged social position will benefit more than oppressed ones: 'rights differently empower different social groups' (Brown 2000, p. 232).

Moreover, legal recognition of subaltern groups, by the juridical codification of the disenfranchised identity - for activists struggling for socio-economic improvements, this could mean being recognised as poor - may operate a re-subordination by 're-naturalizing that which it was intended to emancipate by articulating' (Brown 1995, p. 88). The hypothetical creation of the right not to be poor would then, to a certain extent, operate as a reinforcing mechanism of socio-economic inequalities. This is because rights discourses can have a regulatory and deradicalising effect through political recognition. This aspect hinges crucially on the kind of recognition granted by a state's institutions; therefore, it seems necessary to look at how the contextual interactions between rights holders and government are played out. In addition, people's understanding of being granted legal recognition may actually be mediated by various collective political processes with the capacity to neutralise the individualising and regulatory effects. The use of law by social movements might even modify legal discourses and practices in progressive ways.

The recognition of a right to land or a right to housing may have concrete effects on the legal system itself: Brown describes this process as 'installing within the legal system an analysis of the material basis of subordination' (ibid., p. 126). Yet, not only is the formal recognition of an entitlement not enough in itself to trigger a real change of societal relationships but also pushing liberal legal systems toward acknowledging the material basis of subordination will likely end up with paradoxes: 'to render class exploitation illegal [...] it would entail circumscription, if not elimination, of the right to private property, one of the most fundamental rights of liberal capitalist orders' (ibid., p. 128). For Brown, then, the practice of legal discourse by radical activists is useful as long as they treat rights as 'empty signifiers' in the sense that they help in building a 'fictional egalitarian imaginary', yet without becoming tools for regulating and de-radicalizing movements and activists (ibid., p. 130).

In contrast to traditional socio-legal scholars like Scheingold, Brown's approach to rights considers them from a perspective that incorporates social and political structures. Yet, her conclusions resemble that tradition, in which she argues that rights cannot be used to destabilise the system from within and that they are useful only as mobilising tools.

\section{The Governmentality Studies Perspective}

The Governmentality Studies literature hints at how rights are tools of neoliberal rationalities of government, creating the (free) subjects needed by the indirect and minimal forms of interventions prescribed by the contemporary conduct of conducts (see Odysseos 2010; 
Sokhi-Bulley 2013). Scholars in the social sciences, coming from different disciplines such as international relations, history and political science, have adopted Foucault's critical equipment $^{2}$ to analyse the role of law and rights in global politics. Through the prism of governmentality, the social construction of the international human rights regime has been subject to critique in highlighting the role of law as a disciplinary mechanism and as an element functional to the global governance of conducts (see e.g. Evans 2005; Manokha 2009; Rajkovic 2010).

Critical scholars further explore the interrelation between rights and neoliberalism. Louiza Odysseos (2010), Bal Sokhi-Bulley (2011, 2013) and Anna Selmeczi (2015) illustrate how the functioning logic of (human) rights is the product of neoliberal techniques of government. Rights promote individual self-government through the creation of free subjects; they create the conditions for the exercise of a freedom that is part of a neoliberal governmental rationality: individuals are free to invest their human capital in well-functioning free markets.

Sokhi-Bulley (2013, p. 231), following a Foucauldian analysis of neoliberal governmentality - which can be understood both as the process of government and as a methodology of government - conceives human rights as a tool for the creation of subjects who are free, autonomous and self-governing. In fact, neoliberal governmentality, rather than directing human lives authoritatively, uses rights and freedoms as indirect ways to regulate the social realm. As Selmeczi (2015, p. 1079) argues, neoliberalism prescribes minimal intervention and governing at a distance:

Government should be understood as dependent upon creating both the conditions of freedom and the subject able to exercise that freedom; [...] then (human) rights are revealed as themselves producing freedom; a kind of freedom that, in encouraging selfgovernment, is conducive to (neo)liberal governmental rationalities.

However, the Governmentality Studies literature not only underlines the role of law and rights in creating subjects amenable to neoliberal governmentalities. Often the same scholars-like Odysseos (2016) and Selmeczi (2011) ${ }^{3}$ —open the analysis to include more nuanced visions. They argue that by centring the focus on the oppressed, on the people who actually struggle against 'socio-economic disposability' (Odysseos 2015), (human) rights become multifaceted. For instance, sometimes they are used to 'disrupt logics of dispossession' (Montesinos Coleman 2015) and to build 'counter-hegemonic legal engagements' (Sieder 2011). Selmeczi (2015) provides a compelling discussion of the complex relationship between law and collective struggle in the case of the South African shack-dwellers' movement Abahlali baseMjondolo. Starting with a critique of the assumption that 'codified rights are illusionary' (p. 1077) compared with the brutal existence of neoliberal governmentalities, she argues that the strategic use of 'technologies of citizenship' can counter illegal evictions - 'the most direct form of Abahlali's oppression' (p. 1083). South African activists showed, by making reference to the law and discussing collectively legal texts, that they have voice and they act as political subjects, resisting a politics which renders them 'illiterate and superfluous' (p. 1081). Abahlali's motto 'From Shack to Constitutional Court' is a powerful representation of how legal strategies can be used to resist the system through its own means.

The nuanced perspective of Governmentality Studies on the multiple possible effects of the law points to the core of the conundrum: on the one hand, rights are inscribed in (neo)liberal

\footnotetext{
${ }^{2}$ See especially the lectures Foucault delivered at Collège de France from 1975 to 1979.

${ }^{3}$ See also the second part of Selmeczi (2015).
} 
rationalities of government (and therefore co-optive). On the other hand, this alone is not enough to reject them all together; sometimes, law and rights are effective partners of radical struggles (and therefore resistant). Unfortunately, this debate leaves us with rich theoretical insights but few elements to concretely evaluate the role of legal strategies for progressive politics.

Moreover, the Governmentality Studies literature oscillates between rights in general and the more specific category of human rights. Within Governmentality Studies, most scholars focus on human rights, yet it is not clear whether their progressive potential can be extended to rights more generally. Possibly, both human rights and rights in general are — at times — able to engender and sustain progressive politics. By bridging Critical Legal Theory and Governmentality Studies, it becomes visible that the law (with its specific concepts and practices) is sometimes able to perform forms of radical resistance. In the next section, by illustrating the MTST politics of rights, I argue that the movement is employing rights discourse and legality in radical and progressive ways.

\section{The MTST Struggle over (and with) Rights}

\section{‘Now this land belongs to us!'}

One of the arguments of James Holston's influential book Insurgent Citizenship is that from the end of the military dictatorship in 1985, the struggles of the Brazilian working class focused more intensively on improving access to the city rather than enhancing labour conditions (2008, p. 4). Holston employs a nuanced understanding of citizenship as a framework to elaborate on Brazilian urban struggles. Before the approval of the democratic Constitution in 1988, citizenship in Brazil worked through processes of differentiation and discrimination. Thus, despite formal access being granted to everyone, citizenship benefits were unequally distributed (ibid., p. 7). The Brazilian scholar Eduardo Marques proposes a similar analysis: he conceptualises the birth of the Brazilian welfare system through the idea of 'regulated citizenship' (2016, p. 35). This system involves providing social protection consistent with the role that workers had in the economy. This kind of 'conservative Welfare State' (Esping-Anderson 1990) granted certain limited rights according to the strategic importance of the specific workers' economic sector (e.g. industrial, banking, civil servants). Such a conservative corporatist system, inspired by Italian fascism, had at its centre the role of the church and family in providing assistance. Therefore, large sectors of the population-especially domestic and rural workers - were excluded from basic social protection (Marques 2016, p. $35)$.

Even though democratisation did not bring progressive politicians and social movements into power, the assent of the new Constitution marked the end of the regulated citizenship regime. Social movements' struggles contributed to the recognition of a set of universal rights in the socio-economic domain. According to Article 6 of the Brazilian Constitution, all citizens have a right to 'housing, education, health, work, leisure, social security, protection of motherhood and childhood, and assistance to the destitute' (Earle 2012, p. 116). Yet, 'the old formulas of differentiated citizenship persist' and the poor living in urban peripheries continue to challenge old injustices through the employment of the Constitution as a useful normative framework (Holston 2008, p. 14). Holston's insurgent citizens also claim the right to legal ownership through the self-construction of housing in the urban peripheries. 
Lucy Earle, drawing on Holston's notion, develops the idea of transgressive citizenship to conceptualise the struggle of a housing social movement in São Paulo- the União dos movimentos de Moradia - The Union of Housing Movements (UMM). The UMM began conducting occupations in abandoned buildings in the city centre throughout the 1990s and 2000s, and it is currently one important node of the network of São Paulo housing movements. In contrast to Holston, Earle emphasises the importance of text-based laws in developing a transgressive conception of citizenship. She argues that, differently from movements which contributed to Brazilian democratisation, the Constitution was employed by the UMM, not in indirect ways to claim the poor's right to have rights but in a very concrete fashion to establish a politics of rights.

Earle highlights how text-based rights work as strong normative references to legitimise movement's actions. The UMM strategy, similarly to its MTST counterpart, is at the border of legality, yet social rights are used as a powerful rhetoric to justify occupations. For instance, Earle reports this argument by an UMM activist: 'Occupying is a crime, yes, OK. But I have to tell you that for us at the movement, it's not a crime - because the crime, if you think about it, is the government not giving people housing' (Earle 2012, p. 119). Because of the law, the fact that people are homeless becomes more than an injustice, it becomes a crime itself.

The relationship with legality is also characterised by a fundamental ambiguity: in principle, the UMM is not against the legal system, but sometimes it has to employ illegal strategies. Accordingly, Earle reports the statement of one UMM leader: 'But if things aren't happening, we have laws that we have to make work. [...] And then if that doesn't work, the UMM has its other main type of struggle - occupation' (ibid., p. 111). Despite the fact that here legality seems to have priority over illegality (occupations), sometimes: 'we have to become outlaws to get the law to respond to us [a gente tem tem que virar um for a da lei para ser atendida na lei]' (ibid., p. 121). Thus, employing illegal political strategies is justified because it leads to the fulfilment of protected legal rights.

During my fieldwork at Marielle Vive, I encountered similar explanations on the relationship between the MTST and the legal system. For instance, once I asked D.- - a young activist who had been with Marielle Vive since its creation - whether s/he thought that the MTST acted inside or outside of the law, s/he answered:

I think neither inside, nor outside. The movement is in the middle. Because it struggles for something which belongs to us, but nobody gives us. Thus, the movement acts inside the law, because it demands something we are entitled to. However, it also acts outside the law because, according to it, we cannot occupy.

There are similarities in Earle's account of UMM and my experience with the MTST: both movements make an explicit reference to text-based laws to gain political support and legitimacy. Yet, the interrelation between the rights discourse and the struggle is for MTST activists crucial: written rights are not enough, because activists know that housing will materialise only through a long and arduous political struggle. The main site of both MTST and UMM politics are occupations, and even though these unfold differently between the two movements, I believe they serve a similar function. In addition, as Earle writes, building occupations are 'something more than civil disobedience. [...] In the grounding of occupations in a politics of rights, they become acts of citizenship, albeit transgressive ones' (2012, p. 121).

As Isin (2008) argues, acts of citizenship transform forms of being political and produce new actors. At Marielle Vive, through a collective process of learning and discussing social rights, occupiers became political. Occupations bring into being a new set of social 
relationships. This transformation becomes evident from the way in which activists delineate their affiliation to the movement. C., an occupier at Marielle Vive, once told me: 'In that moment I realised I will forever stay in the movement'. Earle describes the creation of committed and resisting subjectivities too; she reports the statement of an UMM activist: 'when people identify with the struggle, when someone begins to realize that housing is their right, and that that right is being denied, this really unites people at the grassroots of the movement. From that moment you get that kind of consciousness, you'll never stop participating in some kind of way' (Earle 2012, p. 115).

There exist also differences between the MTST's and the UMM's politics of rights. The first is a radical movement which struggles for housing but also tries to organise the urban peripheries to transform capitalist society. The MTST does not implement the law; rather, it employs it as a strategic tool to conduct a luta - the struggle. When the movement succeeds in constructing new apartments for occupiers, the victory does not follow a court's decision, but rather years of pressure on political institutions.

However, the reference to the law and to rights serves the purpose of appropriating the tools of the system to strategically redirect them and change power relationships. Two nights after Marielle Vive was established, one of the leaders encouraged newcomers in the following way:

It is the owner of this land who is irregular with justice and not us. And there is no reason to feel like we did anything criminal, there is no reason to be ashamed. This land belongs to us now!

The leader was referring to the fact that the land on which the occupation was established has been abandoned for more than 50 years, and therefore, it was not fulfilling the social function's requirement for private property, established by Article 5 of the Constitution. Thus, it was the landowner who was acting against the law and not the movement. Importantly, the rhetorical claim of owning the land illustrates how the MTST employs legal discourse in unexpected and radical ways.

\section{Rights as Counter-Conducts}

The present section connects the MTST rights politics with Foucault's concept of counterconducts and recent analyses of it in relation to resistance and rights politics. The contemporary form of government - the conduct of conducts - meets, in Foucault's work, a concept which embodies the other side of the coin, the possibility of resisting governmental reason. Counter-conducts are ways in which the governed can redirect, subvert and escape government. They lie inside governmental dynamics, because - in Foucault's analytics - power relationships are never unidirectional, and the dichotomy governmentality/resistance loses explanatory power. Death $(2010,2016)$; (Death et al. 2016) has formulated a grid to understand contemporary social protests through the prism of counter-conducts, and his work aims at better grasping the interrelations between forms of resistance and forms of government. With Odysseos and Helle Malmvig, he recently edited a special issue of Global Society (2016) whose contributions represent an effort to develop a theoretical and empirical analysis of counter-conducts as forms of resistance. There, Odysseos explicitly theorises human rights as enabling forms of counter-conducts for the survivors of the 1985 Bhopal gas tragedy (2016).

Whether and how rights can be conceptualised as counter-conducts has also been the focus of Ben Golder (2011, 2015); (Golder and Fitzpatrick 2009), who developed an accurate analysis of the complex and nuanced relationship between Foucault and (human) rights. He 
illustrates how a politics of rights can be employed as a tactical element to reshape contingent power relationships. Furthermore, Golder also argues that rights may develop further than mere tactic, acquiring a strategic role for a more structural change of social relationships.

For Foucault, the power of conducting human lives should not be understood in static terms, or as a power in the hands of someone. Power is rather a mobile field of force relations in continuous evolution and transformation: 'power is everywhere; not because it embraces everything, but because it comes from everywhere' (Foucault 1978, p. 93). The force relations that constitute power structures are modified through various processes and strategies that either transform/reverse them or support/strengthen them (ibid., p. 92). Rights and the law may be instruments to change those relations. This is because although rights discourses are part of neoliberal governmentality, they are always polyvalent:

Discourses are not once and for all subservient to power or raised against it, [...] discourse can both be an instrument and an effect of power, but also a hindrance, stumbling-block, a point of resistance and a starting point for an opposing strategy (Foucault 1978, p. 101).

The Foucauldian idea that inside the exercise of power there are always forms of resistance is connected to the ways in which he theorises the modern form of power that conducts human lives. Inscribed in this form of power, there are always rejections, these are counter-conducts. They are ways of refusing to be conducted in certain ways and by certain people. They are inscribed in contemporary techniques of government; as Foucault argued in regard to revolts against the pastoral power of the church: 'The struggle was not conducted in the form of absolute exteriority, but rather in the form of the permanent use of tactical elements that [...] are part, even in a marginal way, of the general horizon of Christianity' (Foucault 2007, p. 215).

Even though Foucault did not analyse possible forms of counter-conducts against neoliberal governmentality, Death argues that a counter-conduct framework can be fruitfully used to analyse recent social movements and protests. Usually, social movements are conceived in terms of clear oppositions: government vs. freedom, power vs. resistance, etc. Yet, such an approach cannot account for the nuances of some protests; indeed, contemporary politics is complex and often an idealised representation of social movements 'as either co-opted or revolutionary' is misleading (Death 2010, p. 235). In fact, how can it take into account 'contradictions and ironies thrown up by video footage of a Seattle anti-globalization protestor kicking a Nike sign whilst wearing Nike shoes?' (ibid., p. 235). An approach based on counter-conducts can deal with such complexity because it is grounded in the Foucauldian idea that power is always relational: that it is never here or there, but it circulates. Therefore, the rationality prescribing to humans to interact in markets to find satisfaction for material needs goes together with a counter-rationality that leads them toward the opposite direction: governmentality and counter-conducts are coextensive.

Death illustrates how contemporary forms of resistance can be better understood through a counter-conduct framework. Yet, it is Golder (2015) who provides a compelling discussion of rights as counter-conducts in his analysis of the relationship between Foucault and liberalism. He rejects recent allegations (Behrent and Zamora 2015) addressed to Foucault of a conversion to humanism and liberalism in his late writings and argues that Foucault's use of (some) liberal tools can indeed be understood through the prism of counter-conducts.

Golder sees this incursion into the liberal field as a productive possibility to redirect and reject oppressive forms of power. He understands the politics of rights as a critical counter- 
conduct. In the political struggle of the governed, rights play a tactical role, they can be used instrumentally to obtain certain ends. To illustrate this idea, Golder uses the powerful metaphor of a game: given the liberal political order as the playing field, rights are allowed to be used by the game's rules, yet they can be employed 'not respecting the game stated purpose' (2015, p. 117). According to him, through a critical counter-conduct of rights, 'one can play the game against itself, use the rules of the game in a way not envisioned by its makers, and indeed attempt to use the tools of rights in order to play a different game entirely' (ibid., pp. 116-117).

The MTST politics of rights achieves something very close to Golder's understanding of critical counter-conducts. The movement employs rights as an effective tactic to produce resisting subjectivities in occupations. Furthermore, the MTST does not refer to the law merely because it wants to apply it; activists twist legality, often toward unexpected and radical directions (as in the case of Marielle Vive's leader claiming ownership over the occupied land). To further illustrate how the MTST enters the legal liberal discursive field to stretch it according to its own interests, I present below an ethnographic glimpse into one demonstration.

After 2 months of negotiations with public institutions and the landowner, Marielle Vive's activists decided to organise a demonstration to go to the court that had to rule on the eviction request filed by the landowner. The occupation wanted to secure more time for negotiations:

We arrive in front of the court in a sunny afternoon; the march was long, and everyone is tired, but as we see the building, occupiers start to celebrate loudly by singing the movement's slogans. F. - one of Marielle Vive's leaders - takes the loudspeaker and explains why everyone is protesting: there is a piece of land unused for over fifty years and more than 3000 families demanding their right to housing to be fulfilled. I see that, while talking, s/he looks at the court, as s/he wanted to catch the attention of the people inside. Despite the fatigue, one line of activists is holding the occupation's banner in front of the entrance, protected by few policemen.

F. - a MTST lawyer - enters the building to meet the judge. It has been no longer than twenty minutes when s/he comes back with two women from the Defensoria Publica-Public Defender, a public body which represents people who cannot afford a lawyer. They briefly talk with the leaders. The moment everyone realizes this, people move closer to better follow what is going on. After a while the leader takes back the loudspeaker, this time smiling:

'Comrades, the judge is counting the days of our [eviction] term without weekends and holidays: this means we will stay longer in our occupation [an outburst of joy follows]. Today we reached a fundamental victory; whoever thought that the struggle does not make a difference can start to change his mind. With this longer term, I am sure, we will have the conditions to continue our struggle in the land and demand an alternative for our housing from public institutions. Our demonstration of today has been fundamental for this to happen!'

While leaving, I am chatting with the lawyer and the leader. The first explains that s/he did not have any appointment, and thus the judge was annoyed. F. very kindly explained the movement's concerns; s/he also spoke rapidly so that the judge could not interrupt her/him. During the conversation, the judge asked F. whether the movement gave notice for the demonstration - I am sure the court's staff were very surprised to see three thousand people at their entrance. F. replied: 'certainly we gave notice, through social 
media; moreover, peacefully demonstrating is our right protected by the constitution...' The judge abruptly asked: 'which constitution?' We cannot really feel outraged about this comment, as we are too happy for the longer term achieved today.

This event shows the tight interrelation that rights discourse and legality have with the struggle in MTST politics. In the movement, activists do not value the law in itself, but rather employ it as a political tactic. It is in this vein that the march to meet the judge can be understood. Marielle Vive needed more time to continue their political negotiations; therefore, the activists decided to strategically move on the tribunal to claim a temporal extension. Furthermore, the discourse used by F.-the MTST lawyer-points to an employment of legality as counter-conduct: both s/he and the judge knew that the movement achieved a fundamental surprise effect in showing up without an appointment and in such considerable numbers, yet F. used the rules of the game to play a different game entirely.

MTST politics, as illustrated by the previous ethnographic glimpse, helps moving beyond a dichotomic understanding of governmentality and resistance. Activists walk on a slippery terrain in their confrontation with government: they move at the edge of governmentality. On the one hand, they accept the opponent's field: in fact, there is an implicit recognition of the court's authority by the fact of marching there. On the other hand, activists' collective strength represents a possible threat for government, as it seems a conscious decision to stop in front of the court and not disrupt its functioning. Interestingly, the very fact that the MTST lawyer talks rapidly to the judge - to avoid interruptions - shows how the concept of counter-conducts fits into MTST strategy: the movement is asking to be governed differently.

Finally, the activist's framing of the demand of housing in terms of rights illuminates the fact that rights discourse can be both an instrument of power and a starting point for resistance. As shown by Foucault, the contemporary conduct of conducts creates freedoms and rights because this is the way in which subjects are governed:

The new governmental reason needs freedom therefore, the new art of government consumes freedom. It consumes freedom, which means that it must produce it. It must produce it, it must organize it. The new art of government [...] formulates simply the following: I am going to produce what you need to be free (Foucault 2008, p. 63).

Here, Foucault shows that freedom - and the rights which established it-regulates the contact between the governed and government: in fact, freedom is part and parcel of the power relations established by modern governmentality. Starting from this analysis, Governmentality Studies literature has convincingly argued that (human) rights discourse can be fruitfully understood as a governmental technique that produces free subjects.

However, when MTST activists demand housing because it is their right, they are deploying a tactic of critical counter-conduct. First, they are demanding to be governed differently, as they are not asking just any kind of housing, but decent housing. Thus, they are fighting against the structural inequalities which force millions of Brazilian into precarious living conditions. Second, as suggested by Golder, they are using the rules of the game in ways not envisioned by its makers: the tactical use of rights discourse helps in constituting occupations, spaces where radical collectivities struggle against capitalism. 


\section{Conclusion}

In the present paper, I have argued that the MTST rights politics aims at broader objectives than just obtaining housing for the homeless of Brazil's urban peripheries. Occupations - the movement's most important tool-are collective spaces in which new political subjectivities emerge. Through processes of learning about social rights, Marielle Vive's activists become politicised and ready to conduct a long and hard struggle. Without the necessity of conceptual stretching, MTST occupations can be framed through Isin's (2008) notion of 'acts of citizenship', as transformative acts that create new rights claimants. Yet, as the following quotation from a Marielle Vive's leader shows, politicising processes in occupations do not merely aim to obtain social rights:

The movement is not only the struggle for our right to housing, but also about creating a new relationship of solidarity and unity. This is why we have common kitchens here. Our struggle is like sowing the seeds of the new society we want to establish: with respect for workers, women and children.

The MTST struggle is broader than obtaining housing: the movement wants to transform capitalistic social relations. This explains why, in contrast to comparable cases analysed by Holston and Earle, the concept of citizenship loses traction in providing a meaningful interpretation of MTST politics. However, I argued that there also exists a more subtle reason. The movement's rights politics is inescapably linked to the concept and practice of the political struggle-a luta. Activists do not employ legal strategies and rights discourse because they believe they will be able to guarantee victory. Rather, rights discourse is mobilised as a tactic to be used against liberal discourse and institutions.

The reference to the constitution to established text-based rights is not enough for the MTST: without the persistence and determination of a struggle which requires devotion and sacrifices, victory will not be attained. In this vein, the rights politics of the MTST can be conceptualised as counter-conducts: as productive ways to enter the governmental field and subsequently leave it with transformed power relations. Thus, the present analysis of MTST politics can be related back to Wendy Brown's concerns about legalistic politics: rights are actually mobilised in radical ways that go beyond their employment as empty signifier. Rights perform two functions for the MTST: on the one hand, they aid in the emergence of politicised subjectivities in occupations; on the other hand-as counter-conducts - they represent forms of resistance to neoliberal practices of government.

However, a promising line for further research is to investigate how activists transform once they obtain housing. Taking Brown's critique of legal discourse as de-radicalising as the starting point for future analyses, the problem involves the MTST's ability to counter these tendencies and progressively move toward the blossoming of the new society they want to establish.

Acknowledgements I would like to thank MTST activists for their patience with a gringo ethnographer. A luta é pra valer!

Funding Information Open access funding provided by Central European University. 
Open Access This article is licensed under a Creative Commons Attribution 4.0 International License, which permits use, sharing, adaptation, distribution and reproduction in any medium or format, as long as you give appropriate credit to the original author(s) and the source, provide a link to the Creative Commons licence, and indicate if changes were made. The images or other third party material in this article are included in the article's Creative Commons licence, unless indicated otherwise in a credit line to the material. If material is not included in the article's Creative Commons licence and your intended use is not permitted by statutory regulation or exceeds the permitted use, you will need to obtain permission directly from the copyright holder. To view a copy of this licence, visit http://creativecommons.org/licenses/by/4.0/.

\section{References}

Behrent, M., \& Zamora, D. (Eds.). (2015). Foucault and neoliberalism. Cambridge: Polity Press.

Boulos, G. (2014). Porque Ocupamos? Uma introdução a luta dos sem-teto [Why do we occupy? An introduction to the homeless struggle]: Autonomia Literaria.

Brown, W. (1995). Rights and identity in modernity: revisiting the "Jewish question". In A. Sarat \& T. M. Kearns (Eds.), Identities, politics, and rights (pp. 85-130). Michigan: University of Michigan Press.

Brown, W. (2000). Suffering rights as paradoxes. Constellations, 7(2), 230-241.

Brown, W. (2004). "The most we can hope for..." human rights and the politics of fatalism. The South Atlantic Quarterly, 103(2-3), 451-463.

Brown, W., \& Halley, J. (2002). Introduction. In W. Brown \& J. Halley (Eds.), Left legalism/Left critique (pp. 137). Durham: Duke University Press.

Death, C. (2010). Counter-conducts: a Foucauldian analytics of protest. Social Movement Studies, 9(3), $235-251$.

Death, C. (2016). Counter-conducts as a mode of resistance: ways of "not being like that in South Africa". Global Society, 30(2), 201-217.

Death, C., Odysseos, L., \& Malmvig, E. (2016). Counter-conduct in global politics: theorising the subjects and practices of contesting conduct. Global Society, 30(2), 151-156.

Earle, L. (2012). From insurgent to transgressive citizenship: housing, social movements and the politics of rights in São Paulo. Journal of Latin American Studies, 44(1), 97-126.

Epp, C. (1998). The rights revolution. Lawyers, activists, and supreme courts in comparative perspective. Chicago: University of Chicago Press.

Esping-Anderson, G. (1990). The three worlds of welfare capitalism. Princeton: Princeton University Press.

Evans, T. (2005). International human rights law as power/knowledge. Human Rights Quarterly, 27(3), 10461068.

Foucault, M. (1978). The History of Sexuality (Vol. 1: An Introduction). New York: Pantheon Books.

Foucault, M. (2007). Security, territory, population: lectures at the Collège de France, 1977-1978. Basingstoke and New York: Palgrave Macmillan.

Foucault, M. (2008). The birth of biopolitics: lectures at the Collège de France 1978-1979. Basingstoke and New York: Palgrave Macmillan.

Gabel, P. (1984). The phenomenology of rights-consciousness and the pact of the withdrawn selves. Texas Law Review, 62, 1563-1600.

Golder, B. (2011). Foucault's critical (yet ambivalent) affirmation: three figures of rights, Social \& Legal Studies, 20(3), 283-312.

Golder, B. (2015). Foucault and the politics of rights. Stanford: Stanford University Press.

Golder, B., \& Fitzpatrick, P. (2009). Foucault's law. London: Routledge.

Goulart, D. (2011). O anticapitalismo do movimento dos Trabalhadores sem teto-MTST [The anti-capitalism of the homeless workers' movement]. (PhD dissertation), Universidade Estadual Paulista,

Holston, J. (2008). Insurgent citizenship: disjunctions of democracy and modernity in Brazil. Princeton: Princeton University Press.

Isin, E. (2008). Theorizing acts of citizenship. In E. Isin \& G. Nielsen (Eds.), Acts of citizenship (pp. 15-43). London: Zed.

Isin, E. (2009). Citizenship in flux: the figure of the activist citizen. Subjectivity, 29(1), 367-388.

Kennedy, D. (2002). The critique of rights in critical legal studies. In W. Brown \& J. Halley (Eds.), Left legalism/ Left critique (pp. 178-228). Durhan: Duke University Press.

Manokha, I. (2009). Foucault's concept of power and the global discourse of human rights. Glob Soc, 23(4), $429-452$.

Marques, E. (Ed.). (2016). São Paulo in the twenty-first century: spaces, heterogeneities, inequalities. London: Routledge. 
McCann, M. (1994). Rights at work: pay equity reform and the politics of legal mobilization. Chicago: University of Chicago Press.

McCann, M. (2006). Law and social movements: contemporary perspectives. Annual Review of Law and Social Science, 2, 17-38.

Montesinos Coleman, L. (2015). Struggles, over rights: humanism, ethical dispossession and resistance. Third World Quarterly, 36(6), 1060-1075.

MTST. (n.d.). As linhas politicas do MTST [The political guidelines of MTST]. Retrieved from http://www.mtst. org/quem-somos/as-linhas-politicas-do-mtst/. Accessed 31 Oct 2018.

Odysseos, L. (2010). Human rights, liberal ontogenesis and freedom: producing a subject for neoliberalism? Millennium: Journal of International Studies, 38(3), 747-772.

Odysseos, L. (2015). The question concerning human rights and human rightlessness: disposability and struggle in the Bhopal gas disaster. Third World Quarterly, 36(6), 1041-1059.

Odysseos, L. (2016). Human rights, self-formation and resistance in struggles against disposability: grounding Foucault's "theorizing practice" of counter-conduct in Bhopal. Global Society, 30(2), 179-200.

Rajkovic, N. (2010). 'Global law' and governmentality: reconceptualizing the 'rule of law' as rule 'through' law. European Journal of International Relations, 18(1), 29-52.

Rosenberg, G. (1991). The hollow hope: can courts bring about social change? Chicago: University of Chicago Press.

Sarat, A., \& Scheingold, S. (Eds.). (2006). Cause lawyers and social movements. Stanford: Stanford University Press.

Scheingold, S. (2004). The politics of rights, lawyers, public policy, and political change. Ann Arbor: University of Michigan Press.

Selmeczi, A. (2011). 'From shack to the constitutional court': the litigious disruption of governing global cities. Utrecht Law Review, 7(2), 60-76.

Selmeczi, A. (2015). Who is the subject of neoliberal rights? Governmentality, subjectification and the letter of the law. Third World Quarterly, 36(6), 1076-1091.

Sieder, R. (2011). 'Emancipation' or 'regulation'? Law, globalization and indigenous peoples' rights in post-war Guatemala. Economy and Society, 40(2), 239-265.

Sokhi-Bulley, B. (2011). Government(ality) by experts: human rights as governance. Law and Critique, 22, 251271.

Sokhi-Bulley, B. (2013). Human rights as technologies of the self: creating the European governmentable subject of rights. In B. Golder (Ed.), Re-reading Foucault: on law, power and rights (pp. 229-248). London: Routledge.

Tushnet, M. (1984). An essay on rights. Texas Law Review, 62, 1363-1403.

Publisher's Note Springer Nature remains neutral with regard to jurisdictional claims in published maps and institutional affiliations. 